\title{
PEMBUATAN BIODIESEL DARI CRUDE PALM OIL (CPO) SEBAGAI BAHAN BAKAR ALTERNATIF MELALUI PROSES TRANSESTERIFIKASI LANGSUNG
}

\author{
Yuli Ristianingsih, Nurul Hidayah dan Fradita Wanda Sari \\ Program Studi Teknik Kimia, Fakultas Teknik, Universitas Lambung Mangkurat \\ Jln. A. Yani KM 35,5 Banjarbaru Kalimantan Selatan
}

\begin{abstract}
ABSTRAK
Biodiesel merupakan bahan bakar alternatif yang diproduksi dari senyawa kimia bernama alkil ester yang bisa diperoleh dari minyak nabati, di mana pada penelitian ini digunakan Crude Palm Oil (CPO). Biodiesel juga diperuntukkan sebagai bahan bakar pengganti solar dengan kadar emisi gas buang lebih rendah. Penelitian ini bertujuan mengetahui pengaruh rasio mol umpan CPO:metanol $(1: 3 ; 1: 4 ; 1: 5 ; 1: 6)$ dan berat katalis $(0,25 \% ; 0,5 \% ; 1 \%)$ terhadap yield biodiesel dan karakteristik biodiesel dengan bahan baku CPO. Penelitian ini dilakukan dengan proses transesterifikasi langsung untuk mengkonversi trigliserida menjadi metil ester (biodiesel). Transesterifikasi dilakukan selama 1 jam pada suhu $65^{\circ} \mathrm{C}$ dengan menggunakan katalis $\mathrm{NaOH}$. Hasil transesterifikasi dipisahkan antara biodiesel dan produk samping gliserol. Biodiesel kemudian dianalisa nilai flash point, pour point, specific gravity dan viskositas kinematik serta dilakukan analisa GC-MS untuk mengetahui komposisi dan kandungan metil esternya. Biodiesel dengan yield terbanyak diperoleh pada rasio umpan 1:3 dan berat katalis 1\% dengan nilai yield sebesar 65,38\%. Biodiesel dengan yield terbanyak ini mempunyai nilai flash point sebesar $81,5^{\circ} \mathrm{C}$, pour point sebesar $15^{\circ} \mathrm{C}$ specific gravity sebesar 0,8719 dan viskositas kinematik sebesar 4,459 $\mathrm{mm}^{2} / \mathrm{s}$. Berdasarkan analisa GC-MS, diketahui kandungan metil ester dalam biodiesel sebesar 54,75\%. Dari hasil penelitian diketahui bahwa semakin besar rasio mol CPO:metanol maka semakin besar pula yield biodiesel, serta semakin besar berat katalis maka semakin besar pula yield biodiesel. Nilai pour point, specific gravity dan viskositas kinematik sudah sesuai dengan SNI, sedangkan nilai flash point masih belum memenuhi SNI. Pembuatan biodiesel dari CPO melalui proses transesterifikasi langsung dapat menghasilkan senyawa metil ester.
\end{abstract}

Kata Kunci: biodiesel, CPO, transesterifikasi

\section{PENDAHULUAN}

Cadangan energi fosil Indonesia sudah sangat terbatas, cadangan minyak hanya cukup untuk 18 tahun, gas untuk 60 tahun dan batu bara untuk 150 tahun. Berdasarkan data dari Sekretariat Panitia Teknis Sumber Energi, distribusi penggunaan sumber energi nasional untuk Bahan Bakar Minyak (BBM) sebesar 60\%, gas 16\%, batubara 12\%, listrik 10\% dan LPG 1\% dari total 606,13 juta SBM (setara bahan bakar minyak). Keadaan ini memacu Indonesia untuk mencari dan memanfaatkan potensi sumber-sumber energi alternatif. Sumber energi alternatif yang dikembangkan di Indonesia antara lain dari Crude Palm Oil (CPO), Palm Fatty Acid Distillate (PFAD), dll (Prihandana et al., 2006).

Bioenergi adalah energi alternatif dimana bahan baku yang digunakan bersifat renewable. Salah satu jenis bioenergi adalah biodiesel. Biodiesel merupakan bahan bakar alternatif yang

Korespondensi

Email: risschma.tekim0213@gmail.com 
diproduksi dari senyawa kimia bernama alkil ester yang bisa diperoleh dari minyak nabati seperti minyak kelapa sawit dan jarak pagar. Biodiesel dari minyak mentah biasanya dihasilkan melalu beberapa tahapan yaitu degumming, refining, esterifikasi dan transesterifikasi. Biodiesel (methyl ester) terbentuk melalui reaksi antara senyawa ester dengan senyawa alkohol sehingga terbentuk senyawa ester baru (methyl ester). Bahan ester ini memiliki komposisi yang sama dengan bahan bakar solar, sehingga, biodiesel ini dapat dimanfaatkan untuk mengurangi konsumsi solar (Negara, 2009).

Pemanfaatan biodiesel sebagai pengganti minyak solar dengan bahan baku CPO yang dapat diperbaharui telah diteliti sebelumnya. Pada penelitian tersebut, konversi tertinggi yaitu sebesar $70,4 \%$ dicapai pada temperatur $110^{\circ} \mathrm{C}$, dengan rasio reaktan metanol : CPO sebesar $7: 1$ dan waktu selama 60 menit (Hambali and Sari, 2009). Penelitian ini difokuskan pada pengolahan CPO untuk menghasilkan biodiesel melalui proses transesterifikasi langsung. CPO dipilih pada penelitian ini karena semakin pesatnya perkembangan industri pengolahan kelapa sawit di Kalimantan Selatan dan potensi konversi CPO menjadi biodiesel lebih tinggi dibanding bahan baku lainnya. Pada penelitian ini, dengan terkonversinya CPO menjadi biodiesel dapat menjadi sumber energi baru dan terbarukan serta mengurangi konsumsi bahan bakar fosil dengan memanfaatkan potensi industri kelapa sawit di Kalimantan Selatan.

Penelitian ini bertujuan untuk mempelajari pengaruh rasio umpan CPO : metanol terhadap yield biodiesel, mempelajari pengaruh berat katalis terhadap yield biodiesel, mengetahui kandungan metil ester yang terdapat dalam biodiesel dengan analisa GC-MS dan mengetahui karakteristik biodiesel yang dihasilkan meliputi flash point, pour point, specific gravity dan viskositas kinematik.

\section{METODE PENELITIAN}

Bahan-bahan yang digunakan adalah CPO yang diperoleh dari PT. Perkebunan Nusantara XIII Pelaihari, metanol 99\%, $\mathrm{NaOH}$ dan akuades.

\section{Prosedur Penelitian}

Sampel diproses menjadi biodiesel dengan metode transesterifikasi (Encinar et al., 2002). Sampel dan metanol dimasukkan ke dalam labu leher tiga dengan variasi rasio mol reaktan (CPO:metanol) 1:3; 1:4; 1:5; 1:6. Katalis $\mathrm{NaOH}$ juga dimasukkan ke dalam labu leher tiga dan nilai beratnya menjadi variabel tetap (1\% wt). Campuran kemudian diaduk dengan menggunakan stirrer sambil dipanaskan menggunakan pemanas mantel dengan suhu dijaga $65^{\circ} \mathrm{C}$ selama $1 \mathrm{jam}$. Hasil reaksi kemudian dipisahkan antara produk atas dan bawah. Produk atas berupa metil ester dan produk bawah berupa gliserol. Lalu, metil ester dimasukkan kembali ke dalam corong pemisah untuk dilakukan proses pencucian. Akuades ditambahkan ke dalam corong pemisah dengan rasio 1:1 dengan sampel. Kemudian didiamkan sejenak hingga terbentuk lapisan air di bagian bawah. Lapisan air tersebut dikeluarkan. Hasil pencucian berupa metil ester dikeluarkan ke dalam gelas beker, kemudian dikeringkan di dalam oven pada suhu $80^{\circ} \mathrm{C}$ selama \pm 1 jam. Setelah 1 jam, hasil pencucian dikeluarkan dari oven. Metil ester hasil pengeringan tersebut didinginkan hingga suhu kamar. 


\section{Uji Analisis Kuantitatif Biodiesel}

Biodiesel yang dihasilkan kemudian dianalisis secara kuantitatif. Analisis secara kuantitatif dilakukan perhitungan yield dimana biodiesel yang dihasilkan ditimbang untuk ditentukan yieldnya. Penentuan besarnya yield ini dapat dihitung dengan rumus berikut:

$\%$ Yield $=\frac{\text { Berat produk }}{\text { Berat } \mathrm{CPO}} \times 100 \%$

\section{Uji Analisis Kualitatif Biodiesel}

Biodiesel dengan nilai yield tertinggi dianalisis secara kualitatif (SNI 04-7182-2006) yaitu dengan menghitung nilai flash point, pour point, specific gravity dan viskositas kinematik. Selain itu, sampel biodiesel yang didapat juga diuji komposisinya dengan analisa GC-MS.

\section{HASIL DAN PEMBAHASAN}

\section{Analisis Kuantitatif Biodiesel}

Pada penelitian ini, variasi rasio reaktan (CPO: Metanol) yang digunakan adalah 1:3; 1:4; $1: 5$ dan 1:6 dan variasi berat katalis $\mathrm{NaOH}$ adalah $0,25 \% ; 0,5 \%$ dan $1 \%$ dari berat minyak. Variasi rasio reaktan dan berat katalis memberikan pengaruh terhadap yield biodiesel yang dihasilkan. Hal ini dapat dilihat pada Gambar 1.

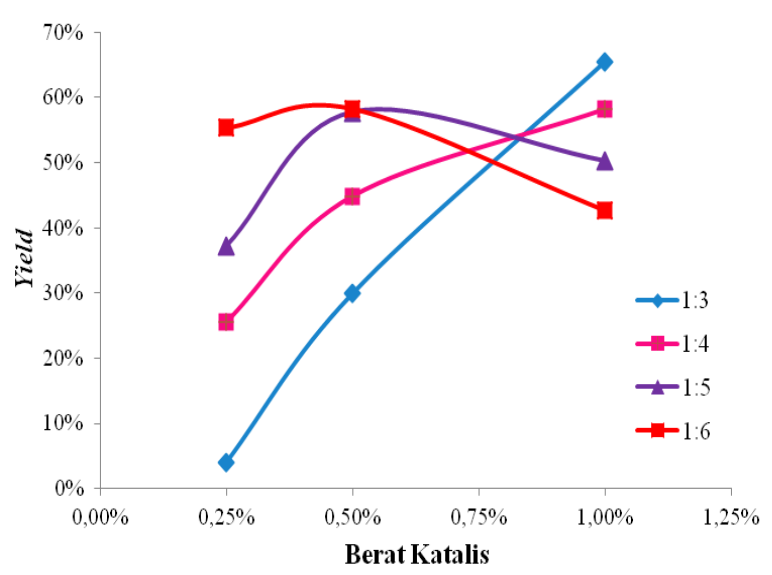

Gambar 1. Hubungan Berat Katalis dan Rasio Reaktan terhadap Yield Biodiesel

Gambar 1. menunjukkan bahwa semakin besar rasio mol reaktan (minyak: metanol maka semakin besar pula yield biodiesel pada berat katalis tetap. Dengan menggunakan metanol berlebih maka reaksi dapat digeser ke kanan (ke arah pembentukan produk) untuk menghasilkan konversi yang maksimum. Hal ini dikarenakan pemakaian salah satu reaktan yang berlebih akan memperbesar kemungkinan tumbukan antara molekul zat yang bereaksi sehingga kecepatan reaksinya bertambah besar (Dharsono and Oktari, 2013). Rasio mol alkohol/minyak juga berpengaruh terhadap distribusi katalis di antara lapisan alkil ester dan gliserol. Rasio mol metanol:minyak 3:1, katalis lebih tertarik ke dalam gliserol, sedangkan dengan penggunaan metanol 
berlebih, katalis akan terdistribusi merata dalam lapisan alkil ester dan gliserol (Encinar et al., 2002).

Gambar 1 juga menunjukkan bahwa semakin besar berat katalis maka semakin besar pula yield biodiesel pada rasio reaktan tetap. Dengan pertambahan jumlah katalis akan meningkatkan kecepatan reaksi sehingga yield biodiesel yang dihasilkan meningkat. Hal ini disebabkan karena dengan besarnya jumlah katalis akan semakin menurunkan energi aktivasi sehingga meningkatkan jumlah molekul yang teraktifkan yang mengakibatkan kecepatan reaksi meningkat (Aziz, 2011). Katalis berfungsi mempercepat reaksi dengan menurunkan energi aktivasi, namun tidak mempengaruhi letak kesetimbangan. Selain itu, penggunaan katalis basa dalam jumlah banyak dapat menetralkan asam lemak bebas di dalam trigliserida. Sehingga, semakin banyak jumlah katalis basa yang digunakan, maka metil ester yang terbentuk akan semakin banyak (Arita et al., 2008).

Penambahan katalis dengan berat $1 \%$ pada perbandingan rasio mol 1:5 dan 1:6 terjadi penurunan yield biodiesel yang dihasilkan dan menyebabkan terbentuknya emulsi. Emulsi yang terbentuk disebabkan oleh reaksi penyabunan yang terjadi akibat penggunaan katalis yang berlebihan. Reaksi penyabunan tersebut akan mengambil sejumlah metil ester yang telah terbentuk. Sehingga akan mengurangi perolehan biodiesel serta menyulitkan dalam pemisahan biodiesel (Yoeswono et al., 2008).

\section{Analisis Kualitatif Biodiesel}

Biodiesel hasil dari reaksi transesterifikasi dengan nilai yield tertinggi selanjutnya dilakukan analisa kualitatif meliputi nilai flash point, pour point, specific gravity, viskositas kinematik dan Gas Chromatography Mass Spectroscopy (GC-MS).

Tabel 1. Hasil Uji Analisis Kualitatif Biodiesel

\begin{tabular}{|l|c|c|c|}
\hline \multicolumn{1}{|c|}{ Parameter } & Satuan & Hasil & $\begin{array}{c}\text { Nilai SNI 04-7182- } \\
\mathbf{2 0 0 6}\end{array}$ \\
\hline Specific gravity & - & 0,8719 & $0,850-0,890$ \\
\hline $\begin{array}{l}\text { Viskositas } \\
\text { kinematik }\end{array}$ & $\mathrm{cSt}$ & 4,459 & $2,3-6,0$ \\
\hline Flash point & ${ }^{\circ} \mathrm{C}$ & 81,5 & Min. 100 \\
\hline Pour point & ${ }^{\circ} \mathrm{C}$ & 15 & Maks 18 \\
\hline
\end{tabular}

\section{Specific Gravity}

Specific gravity biodiesel adalah perbandingan antara densitas biodiesel terhadap densitas fluida standar (air dengan densitas $1 \mathrm{~g} / \mathrm{cm}^{3}$ atau $1000 \mathrm{~kg} / \mathrm{m}^{3}$ ). Nilai specific gravity berkaitan dengan kesempurnaan pembakaran. Nilai specific gravity yang dihasilkan adalah 0,8719 , dengan demikian jika ditinjau dari specific gravity biodiesel maka sudah sesuai dengan standar SNI. Nilai specific gravity yang sesuai dengan standar SNI akan menghasilkan pembakaran yang sempurna. 
Jika nilai specific gravity tidak memenuhi SNI akan menghasilkan pembakaran yang tidak sempurna, sehingga akan meningkatkan emisi gas buang dan mengakibatkan keausan mesin (Yoeswono et al., 2008).

\section{Viskositas Kinematik}

Viskositas minyak dinyatakan oleh jumlah waktu (detik) yang diperlukan oleh volume tertentu dari minyak untuk mengalir melalui lubang dengan diameter tertentu (kecil). Semakin kecil jumlah waktu yang diperlukan untuk mengalir berarti semakin rendah viskositasnya. Viskositas mempunyai peranan yang sangat penting dalam proses penginjeksian bahan bakar. Nilai viskositas kinematik yang dihasilkan adalah $4,459 \mathrm{~mm}^{2} / \mathrm{s}$, dengan demikian jika ditinjau dari viskositas kinematik biodiesel maka sudah termasuk dalam standar SNI. Viskositas terlalu rendah menyebabkan kebocoran dalam pompa injeksi bahan bakar dan jika viksositas terlalu tinggi maka akan mempengaruhi kecepatan kerja alat injeksi dan mempersulit pengabutan bahan bakar (Soerawidjaja, 2003).

\section{Flash Point}

Flash point adalah suatu angka yang menyatakan suhu terendah dari bahan bakar minyak dimana akan timbul penyalaan api sesaat, apabila pada permukaan minyak tersebut didekatkan pada nyala api. Flash point dibutuhkan untuk pertimbangan-pertimbangan keamanan dari penimbunan dan pengangkutan bahan bakar minyak terhadap bahaya kebakaran (Hambali and Sari, 2009). Flash point untuk biodiesel umumnya tinggi (yaitu lebih besar dari $150^{\circ} \mathrm{C}$ ). Batasannya untuk SNI yaitu $100-170{ }^{\circ} \mathrm{C}$. Nilai flash point yang dihasilkan adalah $81,5^{\circ} \mathrm{C}$, dengan demikian jika ditinjau dari nilai flash point biodiesel maka belum memenuhi standar SNI yang mana nilainya minimal sebesar $100{ }^{\circ} \mathrm{C}$. Hal ini dikarenakan kurang optimalnya proses pemurnian sehingga masih ada kandungan metanol dalam biodiesel yang dihasilkan. Dengan adanya alkohol ini dapat menyebabkan kerusakan pada pompa bahan bakar, tangki isian, elastomer, dan dapat menghasilkan daya pembakaran rendah (Departemen Energi Amerika Serikat, 2006).

\section{Pour Point}

Pour point adalah suatu angka yang menyatakan temperatur terendah dari bahan bakar minyak, sehingga masih dapat mengalir karena adanya gaya gravitasi (Hambali and Sari, 2009). Nilai pour point yang dihasilkan adalah $15^{\circ} \mathrm{C}$, dengan demikian jika ditinjau dari nilai pour point biodiesel maka sudah memenuhi standar SNI yang mana nilainya maksimal sebesar $18{ }^{\circ} \mathrm{C}$. Jika nilai pour point rendah maka bahan bakar tidak lagi bisa mengalir karena terbentuknya kristal/gel yang menyumbat aliran bahan bakar, keberadaan kristal di dalam bahan bakar bisa mempengaruhi kelancaran aliran bahan bakar di dalam filter, pompa, dan injektor (Departemen Energi Amerika Serikat, 2006).

\section{Gas Chromatography Mass Spectroscopy (GC-MS)}


Biodiesel hasil dari reaksi transesterifikasi dengan nilai yield tertinggi juga dianalisa kandungan metil ester dengan menggunakan Gas Chromatography Mass Spectroscopy (GC-MS). Analisa ini dimaksudkan untuk mengetahui komponen-komponen yang terkandung dalam biodiesel yang ditunjukkan pada Gambar 2.

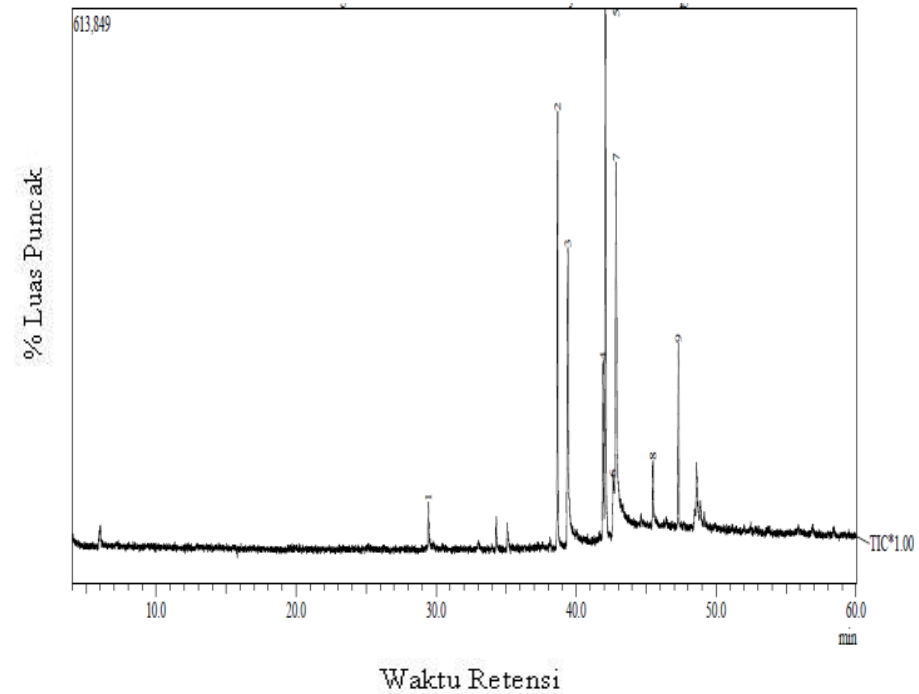

Gambar 2. Analisa GC-MS Biodiesel

Kromatogram yang diperoleh menunjukkan adanya 9 puncak. Puncak tertinggi tercapai pada peak 5 dengan waktu retensi 42,095 menit. Sedangkan puncak terendah tercapai pada peak 1 dengan waktu retensi 29,449 menit.

Hasil analisa GC-MS terkandung senyawa metil ester yang diperoleh pada biodiesel adalah metil laurat, metil palmitat, metil linoleat, metil oleat, dan metil stearat. Senyawa metil ester yang diperoleh tersebut sebagian sesuai dengan kandungan asam lemak yang terdapat pada kelapa sawit (Ketaren, 1986). Pada hasil tersebut masih terdapat asam lemak bebas seperti asam palmitat, asam palmitoleat, dan asam heksanadioat yang masih belum terkonversi menjadi metil ester. Adanya asam lemak bebas tersebut tidak bereaksi dengan metanol dikarenakan penggunaan jumlah katalis yang berlebih sehingga cenderung membentuk reaksi penyabunan dan menghambat pembentukan metil ester. Selain itu, kualitas biodiesel tidak ditentukan dari jenis senyawa yang terkandung di dalamnya, melainkan dari karakterisasi sifat fisik biodiesel (Utami et al., 2012). Kadar biodiesel dapat dihitung dengan membandingkan luas area metil ester yang terkandung dalam biodiesel dengan luas area keseluruhan yang dianalisa pada uji GC tersebut. Kadar biodiesel yang diperoleh adalah dengan kemurnian sebesar 54,75\%. 
Berdasarkan hasil dari penelitian ini dapat disimpulkan:

1. Pengaruh rasio umpan terhadap yield biodiesel yang dihasilkan yaitu semakin besar rasio mol metanol:minyak maka semakin besar pula yield biodiesel. Nilai yield tertinggi didapatkan pada kondisi operasi rasio mol (CPO:metanol) 1:3 dengan nilai 65,38\%.

2. Pengaruh berat katalis terhadap yield biodiesel yang dihasilkan yaitu semakin besar berat katalis maka semakin besar pula yield biodiesel. Nilai yield tertinggi didapatkan pada kondisi operasi berat katalis $1 \%$ dengan nilai $65,38 \%$.

3. Kandungan metil ester yang terdapat dalam biodiesel berdasarkan analisa GC-MS dengan kemurnian sebesar $54,75 \%$.

4. Karakteristik biodiesel yang dihasilkan dilihat dari nilai flash point, pour point, specific gravity dan viskositas kinematik yang masing - masing bernilai $81,5^{\circ} \mathrm{C} ; 15^{\circ} \mathrm{C} ; 0,8719 ; 4,459 \mathrm{~mm}^{2} / \mathrm{s}$. Nilai pour point, specific gravity dan viskositas kinematik sudah sesuai dengan SNI. Nilai flash point masih belum memenuhi SNI.

\section{SARAN}

Saran yang dapat diberikan pada penelitian ini adalah perlunya dilakukan proses pemurnian yang lebih efektif, dengan cara :

1. Pencucian biodiesel dengan akuades dilakukan lebih dari satu kali, sampai diperoleh lapisan air yang jernih.

2. Pengeringan biodiesel menggunakan oven dan dilakukan pada suhu $100^{\circ} \mathrm{C}$. Sehingga, kandungan pengotor dalam biodiesel dapat lebih diminimalisir dan karakteristiknya dapat memenuhi SNI.

\section{UCAPAN TERIMA KASIH}

Penulis mengucapkan terima kasih kepada Laboratorium Operasi Teknik Kimia, Program Studi Teknik Kimia, Fakultas Teknik Universitas Lambung Mangkurat atas fasilitas dan sarana dalam pelaksanaan penelitian ini.

\section{DAFTAR PUSTAKA}

Arita, S., Dara, M. B. dan Irawan, J. (2008). Pembuatan Metil Ester Asam Lemak dari CPO Off Grade dengan Metode Esterifikasi-Transesterifikasi. Jurnal Teknik Kimia, 15, 34-43.

Aziz, I. (2011). Laporan Penelitian Kinetika Reaksi Transesterifikasi Minyak Goreng Bekas. Jakarta: Program Studi Kimia Fakultas Sains dan Teknologi UIN Syarif Hidayatullah.

Departemen Energi Amerika Serikat. (2006). Biomass: Biodiesel Handling and Use Guidelines, New York, U.S. Department of Energy Publishing.

Dharsono, W. dan Oktari, Y. S. (2013). Proses Pembuatan Biodiesel dari Dedak dan Metanol dengan Esterifikasi In Situ. Jurnal Teknologi Kimia dan Industri, 2, 33-39. 
Encinar, J. M., Gonzales, J. F., Rodriguez, J. J. dan Tejedor, A. (2002). Biodiesel Fuels from Vegetable Oil: Transesterifikasi of Cyanara Cardunculus L. Oils with Ethanol. Energy Fuels, 16, 443-450.

Negara, S. D. (2009). Pengembangan Industri Energi Alternatif: Studi Kasus Industri Biodiesel, Jakarta, LIPI Press.

Prihandana, R., Hendroko, R. dan Nuramin, M. (2006). Menghasilkan Biodiesel Murah, Jakarta, AgroMedia.

Setyawardhani, D. A., Distantina, S., Utami, M. D. dan Dewi, N. (2009). Hidrolisis Multistage dan Acid Pre-Treatment untuk Pembuatan Biodiesel dari Minyak Biji Karet. Simposium Nasional RPI VIII

Soerawidjaja, T. H. (2003). Standar Tentatif Biodiesel Indonesia dan Metode - metode Pengujiannya. Forum Biodiesel Indonesia. Bandung.

Yoeswono, Sibarani, J. dan Khairi, S. (2008). Pemanfaatan Abu Tandan Kosong Kelapa Sawit sebagai Katalis Basa pada Reaksi Transesterifikasi dalam Pembuatan Biodiesel. PKMI 2008 . 